\title{
KEBIJAKAN SEKOLAH TERHADAP PENGGUNAAN GADGET DALAM PEMBELAJARAN IPS TERPADU
}

\author{
Diah Nuril Azizah ${ }^{1}$, M. Syafiq Humaisy ${ }^{2}$ \\ ${ }^{1}$ Institut Agama Islam Negeri Ponorogo \\ diahnuril21@gmail.com \\ ${ }^{2}$ Institut Agama Islam Negeri Ponorogo \\ syafiqhumaisi@gmail.com
}

\begin{abstract}
ABSTRAK
Penelitian ini bertujuan untuk mengetahui penggunaan gadget dalam pembelajaran IPS Terpadu di kelas VII C SMP Ma'arif 1 Ponorogo dan untuk mengetahui implementasi kebijakan sekolah dalam penggunaan gadget di SMP Ma'arif 1 Ponorogo. Penelitian ini menggunakan metode penelitian kualitatif yang mana data yang dikumpulkan itu berupa kata-kata, gambar dan bukan angka-angka seperti penelitian kuantitatif. Teknik analisis data dalam penelitian ini menggunakan analisis induktif dan jenis penelitiannya jenis studi kasus. Pengumpulan data dilakukan dengan teknik wawancara, observasi dan juga dokumentasi. Teknik pengecekan keabsahan data dilakukan dengan triangulasi sumber dan triangulsi teknik. Teknik analisis data menggunakan teknik analisis model Miles dan Huberman dengan menggunakan langkah-langkah mereduksi data, penyajian data, dan penarikan kesimpulan. Hasil dari penelitian ini menunjukkan bahwa penggunaan gadget di kelas VII C SMP Ma'arif 1 Ponorogo dalam pembelajaran ips terpadu berfungsi sebagai fasilitas pembelajaran yang digunakan untuk pengerjaan soal, mencari materi yang belum difahami dan mencari materi ips terpadu yang tidak ada dibuku, gadget pada saat jam pelajaran boleh digunakan namun tetap dalam pengawasan guru.
\end{abstract}

Kata kunci: Kebijakan Sekolah; Gadget; IPS Terpadu

\section{ABSTRACT}

This study aims to determine the use of gadgets in Integrated Social Studies learning in class VII C of SMP Ma'arif 1 Ponorogo and to determine the implementation of school policies in the use of gadgets in SMP Ma'arif 1 Ponorogo. This study uses a qualitative research method in which the data collected in the form of words, pictures 
and not numbers like quantitative research. The data analysis technique in this study uses inductive analysis and the type of research is case study. Data was collected by using interview, observation and documentation techniques. The technique of checking the validity of the data is done by triangulation of sources and triangulation of techniques. The data analysis technique uses the Miles and Huberman model analysis technique by using the steps of reducing data, presenting data, and drawing conclusions. The results of this study indicate that the use of gadgets in class VII C SMP Ma'arif 1 Ponorogo in integrated social studies learning functions as a learning facility that is used to work on questions, look for material that has not been understood and look for integrated social science material that is not in the book, gadgets at the time of writing. Lesson hours may not be used but are still under the supervision of the teacher.

Keywords: School Policies; Strings; Integrated IPS

\section{PENDAHULUAN}

Guru dalam dunia pendidikan memiliki peran yang sangat penting untuk menentukan kualitas pembelajaran yang dilaksanakan di kelas atau di ruang praktek. Suhubungan dengan tugas ini, guru hendaknya selalu memikirkan tentang bagaimana upaya yang dilakukan untuk meningkatkan kualitas pembelajaran tersebut, di antaranya dengan membuat perencanaan pembelajaran dengan seksama dan menyiapkan sejumlah perangkat pembelajaran yang tepat guna. Penggunaan media pembelajaran berupa teknologi dalam hal ini sangatlah penting sebagai penunjang proses pembelajaran, mengacu pada UU nomor 20 tahun 2003 pasal 40 ayat 2 tentang sistem pendidikan nasional, pendidikan adalah usaha sadar yang terencana untuk mewujudkan suasana belajar dan proses pembelajaran agar siswa secara aktif mengembangkan potensi diri untuk memiliki kekuatan spiritual keagamaan, pengendalian diri, kepribadian, kecerdasan, akhlak mulia serta keterampilan yang diperlukan negara. Dalam penunjang sisdiknas tersebut dibutuhkan alat atau media pembelajaran, media tersebut bisa berupa teknologi. Teknologi yang digunakan dalam dunia pendidikan bisa berupa laptop, proyektor, dan gadget.

Menurut Mardhi gadget dapat dijadikan sarana menambah pengetahuan siswa tentang kemajuan teknologi sehingga siswa tidak dikatakan menutup mata akan kemajuan teknologi di era globalisasi. Siswa dapat mengakses berbagai informasi edukasi dalam menggunakan gadget, seperti digunakan untuk mencari berbagai informasi mengenai materi yang dianggap sulit terutama dalam penggunaan gadget dalam pembelajaran IPS terpadu. Berdasarkan pengalaman yang diketahui peneliti, penggunaan gadget di sekolah bukan suatu hal yang biasa. Kebanyakan lembaga sekolah tidak memperbolehkan siswanya untuk membawa gadget di sekolah, contohnya pada sekolah-sekolah 
swasta di Bojonegoro dan juga sekolah negeri di Ponorogo sendiri yaitu Madrasah Mts dan Aliyah Abu Dzarrin Bojonegoro dan juga Madrasah Mts dan Aliyah Al Hadi Padangan Bojonegoro.

SMP 1 Ma'arif Ponorogo merupakan salah satu sekolah dari sekolah-sekolah lainnya di Indonesia yang memperbolehkan siswanya untuk menggunakan dan membawa gadget di sekolah. Namun dalam penggunaannya berdasarkan observasi pada magang 1 yang telah dilakukan oleh peneliti pada tahun $2019 \mathrm{di}$ SMP 1 Ma'arif Ponorogo, ada pembatasan dalam penggunaannya. Beberapa jenis pembatasan yang diterapkan yaitu dalam penggunaan gadget atau smartphone, siswa hanya diperbolehkan mengoperasikannya sesuai dengan perintah guru pada saat pembelajaran. Hal itu jika sangat dibutuhkan kalau tidak dibutuhkan gadget tidak boleh digunakan di dalam kelas apalagi saat pembelajaran. Alasan SMP Ma'arif 1 Ponorogo ini diperbolehkan membawa gadget adalah salah satu fungsi utamanya untuk sarana komunikasi, baik itu antar siswa dengan orang tua, siswa dengan guru, ataupun siswa dengan siswa. Namun seiring berjalannya waktu penggunaan gadget di SMP Ma'arif 1 Ponorogo ini juga berfungsi untuk media pembelajaran, untuk pengerjaan soal, dan untuk pembelajaran lainnya yang membutuhka gadget.

Alasan SMP Ma'arif 1 Ponorogo ini diperbolehkan membawa gadget adalah salah satu fungsi utamanya untuk sarana komunikasi, baik itu antar siswa dengan orang tua, siswa dengan guru, ataupun siswa dengan siswa. Namun seiring berjalannya waktu penggunaan gadget di SMP Ma'arif 1 Ponorogo ini juga berfungsi untuk media pembelajaran, untuk pengerjaan soal, dan untuk pembelajaran lainnya yang membutuhkan gadget. Secara umum manfaat gadget dalam pembelajaran adalah untuk memperlancar interaksi antara guru dengan siswa sehingga akan terciptanya proses belajar mengajar yang efektif dan efisien. Manfaat secara khusus dengan adanya gadget penyampaian materi akan dengan mudah diterima oleh siswa dan mampu meningkatkan kemampuan memahami materi pada siswa. Dengan bantuan gadget, penafsiran yang berbeda antar guru dapat dihindari dan kesenjangan informasi antar guru dan siswa maupun siswa dengan siswa dimanapun keberadaannya. Gadget juga memiliki manfaat yaitu proses belajar mengajar yang akan berlangsung secara menarik dan materi akan tersampaikan dengan jelas.

\section{METODE PENELITIAN}

Penelitian ini menggunakan pendekatan kualitatif, Mengacu kepada Strauss dan Corbin penelitian kualitatif adalah suatu jenis penelitian yang prosedur penemuan yang dilakukan tidak menggunakan prosedur statistik atau kuantifikasi. Dalam hal ini penelitian kualitatif adalah penelitian tentang 
kehidupan seseorang, cerita, perilaku dan juga tentang fungsi organisasi, gerakan sosial atau hubungan timbal balik.

Teknik analisis data dalam penelitian ini menggunakan analisis induktif, dan jenis penelitian yang digunakan dalam penelitian ini adalah jenis studi kasus, yaitu suatu deskripsi intensif dan analisis fenomena tertentu atau satuan sosial seperti individu, kelompok, institusi atau masyarakat. Studi kasus merupakan eksplorasi dari sistem terikat atau sebuah kasus (atau banyak kasus) dari waktu ke waktu melalui pengumpulan data mendalam dan mendetail yang melibatkan sumber-sumber informasi yang banyak dengan konteks yang kaya. Studi kasus digunakan secara tepat dalam banyak bidang. Di samping ini merupakan penyelidikan secara rinci atau setting, satu subyek tunggal, atau kumpulan dokumentasi atau satu kejadian tertentu. Metode yang biasanya dimanfaatkan dalam penelitian kualitatif adalah wawancara, pengamatan (observasi), dan pemanfaatan dokumen. Dalam penelitian ini peneliti menggunakan teknik pengumpulan data yaitu berupa teknik wawancara, observasi dan teknik dokumentasi.

Analisis data dalam suatu metode merupakan bagian paling penting dan paling sulit, karena analisis data digunakan untuk memecahkan rumusan masalah dalam suatu penelitian. Analisis data kualitatif adalah proses mencari dan menyusun secara sistematis data yang diperoleh dari hasil wawancara, catatan lapangan, dan dokumentasi, dengan cara mengorganisasikan data kedalam kategori, menjabarkan kedalam unit-unit, melakukan sintesa, menyusun ke dalam pola, memilih mana yang penting dan yang akan dipelajari, dan membuat kesimpulan sehingga mudah difahami oleh diri sendiri. Teknik analisis data yang digunakan dalam penelitian ini adalah menggunakan konsep Miles dan Huberman yang mengemukakan bahwa aktifitas dalam analisis data kualitatif dilakukan secara interaktif dan berlangsung secara terus menerus sampai tuntas, sehingga datanya sudah jenuh.

Adapun langkah-langkah analisis:

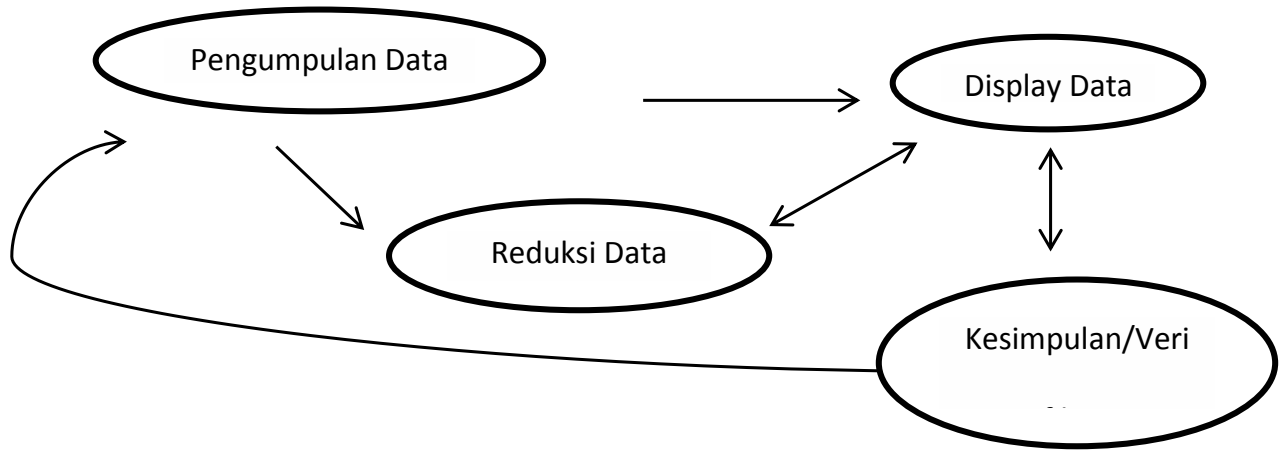




\section{HASIL DAN PEMBAHASAN}

\section{Hasil dan Pembahasan Penggunaan Gadget Dalam Pembelajaran IPS Terpadu.}

Perkembangan teknologi komunikasi dan informasi di SMP Ma'arif 1 Ponorogo sudah berkembang sangatlah pesat. Hal ini dibuktikan dengan hampir seluruh siswa SMP Ma'arif 1 Ponorogo sudah mempunyai dan menggunakan gadget ketika di sekolah. SMP Ma'arif 1 Ponorogo lokasinya juga sangat strategis, dan berada di daerah perkotaan. Oleh sebab itu tidak terpungkiri bahwa siswa-siswi SMP Ma'arif 1 Ponorogo merupakan siswa yang lebih luas pergaulannya dan mungkin pengetahuannya jika dibanding siswa yang berada di sekolah pedalaman. Namun bukan berarti daerah pedalaman adalah daerah yang tertinggal. Sebab tidak sedikit juga lembaga sekolah daerah pedalaman atau daerah pedesaan yang jauh dari kota namun prestasinya tidak kalah dengan sekolah di daerah perkotaan.

Kebijakan sekolah sebagai pernyataan tentang tujuan atau suatu petunjuk mengenai bagaimana sasaran yang bisa dicapai dan bisa dilaksanakan secara bersama dan memberikan kerangka kerja untuk pelaksanaan program sekolah. Berikut telah dinyatakan dalam bukunya Caldwell dan Spinks dalam Beare. Sebuah lembaga sekolah sudah tentu memiliki kebijakan yang berfungsi sebagai sarana tata aturan yang menjadikan sekolah itu tetap eksis di kalangan lembaga serta diakui dan dipercaya oleh masyarakat untuk dapat menjadikan siswa-siswinya menjadi lebih baik dalam segi intelektual baik dalam segi kognitif, afektif maupun dalam segi psikomotorik. Demi mewujudkan hal tersebut sebuah lembaga sekolah perlu adanya untuk mengikuti suatu perkembangan dalam bidang teknologi untuk pendidikan. Dalam kajian pembahasan ini teknologi dalam dunia pendidikan sangat berpengaruh bagi siswa-siswi yang tentunya membutuhkan wawasan pengetahuan yang lebih banyak dan lebih luas.

Oleh karena itu penggunaan teknologi dalam pendidikan sangat berperan penting. Adapun seperti yang telah dipaparkan di dalam materi latar belakang dan dikutip dari sebuah jurnal tunas pendidikan dari Agung Rimba Kurniawan dkk. Menyatakan bahwa teknologi itu bisa berupa laptop, proyektor maupun gadget. Gadget dalam dunia pendidikan sebenarnya keberadaannya sangat membantu dan memudahkan siswa untuk berkomunikasi dengan guru atau dengan orang tua atau sekedar untuk mencari materi yang belum di fahami dan untuk menambah pengetahuan. Namun penggunaan gadget secara berlebihan dan tanpa kontrol orang tua ataupun kontrol guru di sekolah juga bisa membahayakan bagi siswa-siswi itu sendiri. Sebab kita tidak tahu bagaimana siswa-siswi itu mengoperasikan gadgetnya. Sebab selain dari banyaknya dampak positif dari gadget, gadget juga memiliki kekurangan 
dampak negatif yang tentunya tidak sedikit juga. Adapun gadget juga menimbulkan efek ketergantungan terhadap penggunanya. Selain itu menurut Uchjana kemajuan teknologi terutama teknologi komunikasi elektronik telah menimbulan dampak pada siswa dan cenderung menyisihkan hasrat membaca buku di kalangan pelajar. ${ }^{1}$ Efek ketergantungan yang ditimbulkan dari gadget bagi kalangan siswa akan membuat siswa menjadi lebih dominan terhadap gadget sehingga lebih mengutamakan bermain gadget daripada membaca buku. Hal itu merupakan salah satu dampak negatif dari gadget jika digunakan secara berlebihan.

Sebelum adanya pandemi penggunaan gadget dalam pelajaran IPS Terpadu di kelas VII C SMP Maarif 1 Ponorogo bertujuan untuk media pembelajaran. Dalam penggunaannya pada pelajaran IPS Terpadu siswa-siswi kelas VII C SMP Ma'arif 1 Ponorogo memakainya untuk pengerjaan soal, dan juga untuk mencari materi yang belum difahami yang tidak ada dalam buku, yang tentunya hal itu sudah mendapat izin dari guru mata pelajaran dengan kontrol pengawasan dari guru. Terkadang juga ada beberapa dari siswa-siswi kelas VII C SMP Ma'arif 1 Ponorogo yang menggunakan gadget pada saat jam istirahat untuk sekedar searching google tentang materi ips apabila keterangan yang diberikan gurunya belum mereka fahami. Tentu saja hal ini sangat bernilai positif bagi pengetahuan siswa namun hal seperti ini juga yang membuat siswa menjadi malas membaca buku apabila keseringan mencari referensi lewat google yang biasanya google dapat diakses melalui gadget atau smartphone. Oleh sebab itu dalam penggunaan gadget di SMP Ma'arif 1 Ponorogo dibatasi atas kebijakan sekolah yang berlaku agar siswa tidak selalu mengandalkan internet lewat gadget tersebut.

Menurut Hendrastomo dalam Irawan dan Armayanti pesatnya teknologi pada saat ini menimbulkan dampak yang luar biasa bagi manusia, di satu sisi perkembangan teknologi semakin mempermudah pekerjaan manusia, tetapi di sisi lain dari sebagian aktivitas sehari-hari yang tergredatasi akibat kecanggihan teknologi. Teknologi yang semula diciptakan untuk kemudahan dan efisiensi justru di sisi lain semakin mendekontruksi kegiatan manusia. ${ }^{2}$ Seperti yang sudah peneliti jelaskan penggunaan gadget yang berlebihan akan membuat penggunanya menjadi candu, hal ini sejalan dengan teori menurut Hendrastomo diatas bahwa penggunaan teknologi yang semula diciptakan untuk kemudahan justru malah menjarah kegiatan manusia yang membuat

1 Sa'adah, Dampak Penggunaan Gadget Terhadap Perilaku Sosial Siswa di MAN Cirebon 1 Kabupaten Cirebon, Skripsi, 2015, 25.

2 Gin Ginanjar, dkk, Penggunaan Gadget dalam Proses Pembelajaran Ilmu Pengetahuan Sosial Siswa Sekolah Dasar, 2, 2018, 373. 
ia malas melakukan kegiatannya karena terjebak dalam asyiknya bermain teknologi tersebut atau bisa dikatakan gadget.

Pembelajaran IPS Terpadu di kelas VII C SMP Ma'arif 1 Ponorogo memang tidak melulu selalu membutuhkan gadget. Hal itu bisa dilihat dari respon responden ketika ditanya tentang tingkat kesulitan pelajaran IPS Terpadu. Dan rata-rata jawaban dari responden adalah menjawab tidak terlalu sulit namun juga tidak terlalu mudah. Ada juga yang menjawab bahwa sebagian dari responden tidak menyukai pelajaran IPS Terpadu. Sebab dengan alasan bosan karena materinya yang memang sedikit membosankan. Oleh sebab itu penggunaan gadget di kelas VII C SMP Ma'arif 1 Ponorogo dibatasi pada saat jam-jam tertentu saja. Adapun pembelajaran IPS Terpadu dengan menggunakan gadget sebenarnya sangat membantu bagi siswa-siswi VII C SMP Ma'arif 1 Ponorogo itu sendiri. Namun sekali lagi penggunaannya dalam pelajaran IPS Terpadu hanya sekedarnya saja. Kajian materi ips dalam internet memanglah sangat luas oleh sebab itu dengan siswa-siswi mengakses internet untuk kebutuhan pengetahuan materi ips terpadu itu menjadikan siswa lebih aktif dalam pembelajaran daripada tidak mengakses sama sekali. Sebab pengetahuan itu tidak hanya dari buku saja, pengetahuan juga bisa di dapat melalui teman, guru, maupun dari internet yang dihasilkan melalui teknologi baik itu berupa komputer maupun gadget atau smartphone. Namun penggunaan gadget yang berlebihan akan sangat merugikan bagi siswa, seperti yang telah dikutip dalam Kompasiana menurut Erni Sarif dampak negatif penggunaan gadget dalam lingkungan sekolah menjadikan siswa terkadang mengangkat telepon ketika sedang belajar dan hal itu bisa mengganggu konsentrasi belajar siswa, kemudian konsentrasi belajar bisa menurun karena siswa lebih menyukai gadget daripada belajar. ${ }^{3}$

Berbanding terbalik dengan penggunaan gadget saat ini setelah adanya pandemi, sebab dunia sedang digemparkan oleh adanya pandemi covid-19 yang menjadikan semua tatanan baik itu dalam bidang ekonomi, pendidikan, kebudayaan itu sangat berpengaruh dan juga sangat berpengaruh terhadap aktivitas manusia sehari-hari terutama dalam dunia pendidikan saat ini. Dari hal itu pemerintah menggencarkan pembelajaran secara daring atau online. Maka mau atau tidak mau pembelajaran harus dilakukan secara online. Hal ini berpengaruh besar terhadap SMP Ma'arif 1 Ponorogo ataupun sekolah-sekolah lainnya. Pada mulanya sebelum adanya pandemi covid-19 gadget tidak terlalu dibutuhkan pada pembelajaran. Namun setelah adanya pandemi covid-19 gadget sangat dibutuhkan oleh siswa-siswi SMP Ma'arif

3 Erni Sarif, Dampak Penggunaan Gadget dalam Lingkungan Sekolah, Kompasiana, (7 Oktober 2019). https://www.kompasiana.com/ernisarif/5d9ac8c3b13fde56f248e293/dampakpenggunaan-gadget-dalam-lingkungan-sekolah 
1 Ponorogo. Dan tentunya juga berlaku bagi seluruh lembaga sekolah dan juga oleh kalangan mahasiswa. Hampir semua kalangan terkena dampak dari pandemi covid-19 ini. Aktivitas semua terhalang oleh adanya pandemi yang berkelanjutan ini sebab pemerintah menggalangkan psbb (pembatasan sosial berskala besar). Jadi selama pandemi covid penggunaan gadget menjadi sangat dibutuhkan. Dan gadget merupakan sumber fasilitas utama dalam pembelajaran. Hal ini berlaku juga untuk pembelajaran IPS Terpadu yang proses belajar mengajarnya juga selalu menggunakan gadget. Dari semula pembelajaran dengan menggunakan gadget dalam keadaan normal sangat dibatasi terutama di lingkungan sekolah namun setelah adanya pandemi gadget menjadi pelaku utama dalam berjalannya proses belajar mengajar secara online.

Pada intinya penggunaan gadget dalam pembelajaran IPS Terpadu di kelas VII C SMP Ma'arif 1 Ponorogo sangatlah membantu untuk pendalaman materi ips yang belum difahami oleh siswa-siswi. Sebab terkadang tidak semua materi yang diberikan oleh guru bisa difahami saat itu juga oleh siswa, terkadang juga ada beberapa siswa yang introvert dan mereka malu untuk bertanya kepada gurunya dan dengan bantuan gadget yang dilengkapi dengan internet bisa membantu siswa kelas VII C SMP Ma'arif 1 Ponorogo yang masih kesulitan dalam pelajaran ips terpadu.

Adapun tentang kepribadian introvert ini sesuai dengan teori yang dinyatakan oleh Hall dan Lidzey yang menjelaskan bahwa karakteristik dari sifat introvert cenderung pemalu, introspektif, menyukai buku atau kutu buku, tidak terlalu ramah kecuali pada seseorang yang dikenal atau teman dekatnya, mereka juga cenderung merencanakan sesuatu dengan berhatihati sebelum melakukan sesuatu atau mengambil langkah dalam melakukan sesuatu. ${ }^{4} \mathrm{Hal}$ ini sesuai dengan asumsi peneliti bahwa siswa yang cenderung berkepribadian introvert atau tertutup ia akan lebih cenderung pemalu ketika bertanya dengan guru, oleh sebab itu penggunaan gadget di sekolah khususnya untuk pembelajaran IPS Terpadu itu merupakan hal yang cukup membantu ketika mereka malu bertanya dengan guru. Dengan itu siswa yang cenderung introvert tidak lagi ketinggalan pelajaran dengan temannya yang lebih ekstrovert, walaupun mereka introvert atau pendiam kalau ia itu aktif maka seharusnya mereka akan lebih luas pengetahuannya sebab terkadang mereka lebih memilih mencari pengetahuan sendiri dari luar seperti dari buku ataupun gadget itu sendiri. Dan referensi dari gadget ataupun buku menurut peneliti itu malah lebih luas daripada yang hanya diajarkan oleh

4 Widya Zulfa Ulwiyah, "Kepribadian Ekstrovert dan Introvert pada Siswa Kelas VVI G SMP Negeri 2 Ponorogo pada Proses Pembelajaran Dalam Prespektif Psikologi Sosial”, Skripsi, Program Studi Ilmu Pengetahuan Sosial, Institut Agama Islam Negeri Ponorogo, 2020, 107. 
guru. Namun bukan berarti peneliti menyalahkan guru. Tidak seperti itu, sebab tidak selamanya referensi ilmu yang di dapat dari gadget itu valid, terkadang kita harus pandai dalam memilih informasi, sebab informasi atau referensi hoaxs juga banyak tersebar di internet. Jadi agar lebih baiknya selain belajar dari buku dan juga gadget yang terhubung dengan internet ada baiknya bila kita memvalidasi segala informasinya dan menanyakannya pada guru ketika di sekolah.

\section{Hasil dan pembahasan Implementasi Kebijakan Sekolah Dalam Penggunaan Gadget di SMP Ma'arif 1 Ponorogo.}

Penggunaan gadget ketika di sekolah memang masih terbilang jarang digunakan. Banyak lembaga sekolah yang tidak memperbolehkan siswanya untuk menggunakan gadget di sekolah, karena menurut sekolah lainnya penggunaan gadget di sekolah hanya akan mengganggu konsentrasi siswa dalam pembelajaran dan juga lebih banyak mudhorotnya daripada positifnya. Contohnya saja seperti yang telah peneliti paparkan di materi pendahuluan pada latar belakang yaitu ada beberapa contoh sekolah yang diketahui oleh peneliti yang tidak diperbolehkan membawa gadget di sekolah yaitu ada sekolah SMPN 1 Jenangan Ponorogo yang tidak memeperbolehkan siswanya menggunakan gadget di sekolah namun jika ada yang membawa maka gadget harus dikumpulkan di sebuah loker khusus penyimpanan gadget dan ketika pulang sekolah baru boleh diambil. Kemudian ada sekolah di Mts Plus Alhadi Padangan Bojonegoro yang juga tidak memperbolehkan siswanya membawa bahkan mengoperasikan gadget di sekolah dan juga Mts Abu Dzarrin Bojonegoro juga tidak memperbolehan siswanya membawa bahkan mengoperasikan gadget di sekolah. Dan mungkin masih ada beberapa contoh sekolah lainnya yang tidak memperbolehkan siswanya membawa ataupun mengoperasikan gadget di sekolah.

SMP Ma'arif 1 Ponorogo memang bukan salah satunya sekolah yang memperbolehkan siswanya membawa gadget di sekolah dan mungkin diluaran sana juga ada beberapa sekolah yang juga memperbolehkan siswanya membawa dan mengoperasikan gadget di sekolah dan tentunya dengan batasan-batasan dan aturan yang telah di tertibkan seperti halnya di SMP Ma'arif 1 Ponorogo. Hal ini menjadi daya tarik tersendiri bagi peneliti sebab dari pengalaman peneliti masih jarang sekolah yang memperbolehkan siswanya membawa dan mengoperasikan gadget di sekolah. Oleh karena itu peneliti mengambil studi kasus di SMP Ma'arif 1 Ponorogo. Seperti yang telah dipaparkan oleh peneliti dalam penggunaan gadget sudah pasti dan sudah tentu akan ada peraturan tata tertib sekolah yang ditegakkan agar siswa-siswinya tidak melampaui batas dalam penggunaan gadget. Mengingat tidak sedikit pula dampak negatif 
yang ditimbulkan oleh gadget yang lebih parahnya membuat efek candu bagi penggunanya apabila menggunakan secara berlebihan seperti contoh hal kecil menjadi lupa waktu dan lebih parahnya sebagian besar waktu habis hanya digunakan untuk bermain gadget. Oleh sebab itu harus ada batasannya dan batasan-batasan yang diterapkan di SMP Ma'arif 1 Ponorogo adalah dengan membatasi penggunaannya seperti hanya pada saat jam istirahat saja dan itupun juga ada guru piket yang mengawasi dan mengontrol penggunaan gadget bagi siswa-siswinya.

Hamalik dalam Dr Azhar arsyad mengemukakan bahwa pemakaian media pembelajaran dalam proses belajar mengajar dapat membangkitkan keinginan dan minat yang baru, membangkitkan motivasi dan rangsangan kegiatan belajar dan bahkan membawa pengaruh-pengaruh psikologis terhadap siswa. Kemudian Levie dan Lents dalam Dr Azhar arsyad mengemukakan empat fungsi media pembelajaran, khususnya media visual yaitu; sebagai fungsi atensi, fungsi afektif, fungsi kognitif, dan juga fungsi kompensatoris. ${ }^{5}$ Dari teori ini peneliti setuju dengan manfaat penggunaan gadget di sekolah. Dengan diperbolehkannya menggunakan gadget di sekolah untuk pembelajaran siswa menjadi lebih kreatif dan lebih termotivasi untuk melakukan inovasi ataupun penemuan-penemuan baru. Dengan diperbolehkan menggunakan gadget di sekolah dalam pembelajaran juga membantu siswa agar tidak merasakan pembelajaran yang monoton hingga membuat siswa lebih merasa cepat bosan sehingga pelajaran tidak masuk ke otak secara maksimal.

SMP Ma'arif 1 Ponorogo memberi kebijakan penggunan gadget di sekolah dilengkapi dengan adanya program pembentukan organisasi tarunataruni yang langsung di gerakkan oleh tenaga pengajar atau bapak/ibu guru. Tujuan dari dibentuknya taruna-taruni adalah salah satu fungsinya berguna untuk mengontrol siswa-siswi SMP Ma'arif 1 Ponorogo dalam penggunaan gadget di sekolah khususnya pada saat jam istirahat agar siswa-siswinya tidak mengoperasikan gadget kedalam hal yang negatif. Adapun jika terjadi pelanggaran yang dilakukan oleh siswa-siswi maka akan ada sanksi juga. Sanksi itu berupa gadget akan disita dan tidak baru akan dikembalikan pada saat penerimaan laporan hasil belajar siswa di semester kenaikan selanjutnya dan juga untuk siswa yang melanggar peraturan diberi nasehat atau bimbingan konseling agar tidak melakukannya lagi dikemudian hari. Hal ini tentunya agar memberi efek jera pada siswa-siswi yang melanggar peraturan sekolah. Namun dari hasil wawancara yang telah dilakukan oleh peneliti dari salah satu narasumber wawancara bahwa belum pernah ada pelanggaran yang

5 Chandra Anugrah Putra, Pemanfaatan Teknologi Gadget Sebagai Media Pembelajaran, Universitas Muhammadiyah Palangkaraya, 2019, 3. 
dilakukan oleh siswa-siswi SMP Ma'arif 1 Ponorogo. Berarti dari hal ini bisa dikatakan bahwa SMP Ma'arif 1 Ponorogo ini siswa-siswinya sangat tertib.

Berbanding terbalik dengan penggunaan gadget dimasa pandemi saat ini. Karena keberadaan gadget pada masa pandemi lebih diutamakan sebab selama pandemi pemerintah memberlakukan pembelajaran secara daring dan itu juga berlaku untuk semua aktifitas pekerjaan dan lainnya. Semua harus dilakukan secara daring atau online. Oleh sebab itu masa pandemi ini pembelajaran hanya bisa dilakukan melalui sarana gadget sebab tidak memungkinkan jika pembelajaran dilakukan secara offline atau tatap muka. Setiap pelanggaran yang dilakukan akan ada sanksi tersendiri, yaitu berupa gadget akan disita dan baru akan dikembalikan pada saat kenaikan kelas semester selanjutnya kemudian siswa yang melanggar juga dinasehati dan diberi bimbingan konseling agar tidak mengulangi pelanggaran lagi dikemudian hari.

Penerapan penggunaan gadgetdiSMPMa'arif1 Ponorogo memperbolehkan siswanya menggunakan gadget pada saat jam istirahat. Selain memberi kebebasan dalam penggunaan gadget sekolah juga melengkapi dengan petugas kontrol yang sangat ketat untuk mengawasi siswa-siswi SMP Ma'arif 1 Ponorogo yang menggunakan gadget di sekolah dan bertujuan untuk agar siswanya tidak membuka konten porno atau membuka situs negatif lainnya. Seperti yang sudah peneliti paparkan di atas organisasi yang mengawasi ini bernama taruna-taruni yang langsung digerakkan oleh guru SMP Ma'arif 1 Ponorogo. Dengan adanya program ini siswa menjadi lebih terkontrol dan lebih bijak dalam mengoperasikan gadget. Namun hal ini tidak menafikan bahwa tidak akan ada pelanggaran yang dilakukan. Disaat pengawas lengah mungkin saja akan terjadi pelanggaran. Sebab manusia hanyalah manusia yang bisa berencana. Contoh kecil dikantor polisi. Kantor polisi adalah tempat dimana kejahatan diamankan namun disisi lain juga tetap masih ada pelanggaran yang dilakukan oleh pelaku kriminal. Oleh sebab itu ada baiknya jika kita semua harus selalu waspada. Terutama pengawasan guru saat mengontrol siswa-siswinya mengoperasikan gadget di sekolah di SMP Ma'arif 1 Ponorogo ini.

Para ahli prespektif social constructive memandang ruang kelas sebagai lingkungan komunikasi yang dinamis, berkembang dan berbeda. Pemanfaatan teknologi menyediakan sumber daya dan fasilitas untuk pembelajaran dan untuk membangun juga mengaplikasikan ilmunya. Mereka mampu untuk menciptakan, mengedit, dan membagi konten. Terlebih lagi dengan pemanfaatan teknologi di dalam kelas siswa mampu untuk memilih tema lingkungan kelas yang mereka rasakan paling nyaman saat belajar. Siswa selalu disediakan ruang belajar baik secara individu maupun berkelompok. Menyediakan ruang untuk belajar secara individu dan berkelompok adalah 
pintu gerbang pada tendensi sikap manusia untuk mampu bekerja secara individu maupun kelompok. Sebagai konsekuensinya sekolah saat ini telah berpindah dari "mengatakan/mengajarkan" ke pedagogi "anak-anak mengajarkan diri mereka sendiri dengan arahan dari guru" hal ini pernyataan menurut Prensky. ${ }^{6}$ Dengan kebijakan sekolah membolehkan siswanya membawa dan mengoperasikan gadget di sekolah siswa menjadi lebih luas pengetahuannya jika itu digunakan untuk belajar sendiri seperti yang dilakukan oleh beberapa siswa kelas VII C pada saat istirahat, yang menggunakan gadget untuk belajar dan mencari pemahaman materi ips terpadu ataupun materi lainnya yang dirasa belum difahami saat guru menerangkan dikelas.

Pernyataan dari Prensky, peneliti juga membenarkan namun tidak sepenuhnya membenarkan sebab penggunaan gadget di sekolah tidak selamanya dibenarkan. Kita tidak tahu bahwa dunia tidak akan selalu memihak pada hal positif saja, namun dunia juga bisa menjerumuskan kedalam hal yang negatif. Penggunaan gadget di sekolah bagi siswa jika tidak ada kontrol dari guru akan membuat siswa menjadi aktif bahkan terlalu aktif. Dan hal ini tidak menafikan bahwa akan ada pelanggaran yang dilakukan. Seperti siswa bisa saja akan membuka konten terlarang ataupun melakukan kejahatan lainnya di dunia elektronik seperti gadget. Sebab gadget jangkauannya sendiri itu luas apalagi jika gadget itu terhubung dengan internet. Jadi kebijakan sekolah dalam penggunaan gadget di SMP Ma'arif 1 Ponorogo dengan menambahi tata tertib dan pengawasan yang ketat dari guru ini sudah benar dan sudah bagus namun hal ini sebagai pr bagi guru dan sekolah untuk lebih mengawasi dan mengontrol siswa-siswi agar tidak terjadi hal yang tidak diinginkan, karena mengingat dampak negatif yang diberikan gadget itu sendiri. Dan dalam menyikapi hal ini kebijakan sekolah di SMP Ma'arif 1 Ponorogo menegaskan bahwa penggunaan gadget pada aturannya memang tidak di perbolehkan namun gadget akan diperbolehkan apabila memang dibutuhkan dalam pembelajaran dan ataupun untuk berkomunikasi. Mengingat tidak sedikit pula dampak negatif dari gadget, oleh sebab itu banyak sekali sekolah diluaran sana yang memperbolehkan siswanya membawa ataupun mengoperasikan gadget di sekolah. Seperti contoh-contoh sekolah yang telah peneliti jelaskan pada bab sebelumnya. Sebab menurut Kemendikbud penggunaan gadget di lembaga sekolah disesuaikan kepada kondisi sekolah juga. Jika sekolah memungkinkan dan juga disetujui oleh orangtua wali siswa selaku pihak pendidikan anak maka sekolah diperbolehkan menggunakan akes gadget di sekolah. Mengingat dari yang dikatakan Anies Baswedan penggunaan gadget di sekolah terutama di negara Indonesia masih begitu riskan sebab menurut

6 Mahcmud Karmila, Model Kebijakan Integrasi Pemanfaatan Mobile Technology di Sekolah Menengah Atas (Yogyakarta: Depublish), 2018, 3. 
Anies gadget itu seperti pisau bermata dua yang membawa dampak negatif dan juga positif, hal ini sudah peneliti jelaskan pada bab diatas.

Berangkat dari pernyataan Anies Baswedan selaku menteri pendidikan Indonesia saat ini, penggunaan gadget di sekolah itu tergantung dari pihak sekolah tersebut. Ketika sekolah memberikan kebijakan demikian seperti penggunaan gadget di sekolah, maka sekolah juga harus bertanggung jawab akan penggunaan gadget tersebut. Jadi selain membolehkan juga harus ada kontrol dalam penggunaannya. Peneliti setuju dengan pernyataan Anies Baswedan ini sebab dalam lapangan di SMP Ma'arif 1 Ponorogo memang sudah menyiapkan hal demikian. Selain memperbolehkan siswanya membawa gadget di sekolah SMP Ma'arif juga memberikan kontrol pengawasan dari taruna-tarun yang menurut peneliti sudah cukup bagus, dan juga SMP Ma'arif memberlakukan sanksi hukuman apabila ada siswanya yang melanggar aturan yang telah ditentukan sebelumnya.

\section{KESIMPULAN}

Penggunaan gadget dalam pembelajaran IPS terpadu di kelas VII C SMP Ma'arif 1 Ponorogo sangatlah membantu untuk pendalaman materi IPS yang belum difahami oleh siswa-siswi. Penggunaan gadget pada pembelajaran IPS terpadu juga digunakan di dalam kelas namun tidak terlalu sering sebab guru lebih mengutamakan buku daripada gadget. Penggunaan gadget di dalam kelas juga diawasi oleh guru yang mengajar dan apabila ada yang melanggar maka diberlakukanlah sanksi yang telah ditetapkan. Penggunaan gadget di kelas VII C SMP Ma'arif 1 Ponorogo juga digunakan untuk pengerjaan soal dan menambah pengetahuan siswa sehingga siswa menjadi lebih kreatif dan inovatif serta tidak gagap teknologi. Tidak hanya dalam pembelajaran IPS Terpadu hal ini juga berlaku pada semua pembelajaran di kelas VII C SMP Ma'arif 1 Ponorogo yang membutuhkan gadget.

Penerapan atau pengaplikasian kebijakan sekolah dalam penggunaan gadget di SMP Ma'arif 1 Ponorogo ini memperbolehkan siswanya membawa dan mengoperasikan gadget di sekolah dan tentunya dengan batasan-batasan dan aturan yang telah di tertibkan di SMP Ma'arif 1 Ponorogo. Adapun aturan tata tertibnya adalah siswa tidak boleh mengoperasikan gadget pada saat jam pembelajaran berlangsung. Gadget baru diperbolehan apabila memang sangat dibutuhkan saja dan harus dengan izin serta kontruksi dari guru yang mengajar. Kemudian siswa juga diperbolehkan menggunakan gadget pada saat jam istirahat. Pada saat jam istirahat siswa boleh bebas menggunakan gadget namun juga harus dengan pengawasan dari guru yang bertugas mengawasi dan mengontrol penggunaan gadget oleh siswa-siswi SMP Ma'arif 1 Ponorogo. Adapun dalam pembagian tugas mengontrol dari guru ini sekolah membentuk program taruna- 
taruni yang bertujuan untuk mengawasi penggunaan gadget tadi agar siswa-siswi SMP Ma'arif 1 Ponorogo menggunakan gadget dengan lebih bijak dan jauh dari hal-hal yang negatif.

Adapun SMP Ma'arif 1 Ponorogo ini juga memberikan sanksi apabila ada siswa-siswi yang melanggar aturan sekolah dalam penggunaan gadget seperti gadget akan akan disita dan akan dikembalikan pada saat kenaikan kelas semester selanjutnya kemudian siswa yang melanggar akan diberi bimbingan konseling berupa nasehat agar tidak mengulangi lagi kesalahan yang telah diperbuat dikemudian hari. Penggunaan gadget di SMP Ma'arif 1 Ponorogo tidak hanya untuk fasilitas dalam belajar mengajar saja namun juga untuk komunikasi antara guru dan siswa, siswa dengan siswa lainnya, ataupun siswa dengan orangtuanya. 


\section{DAFTAR PUSTAKA}

Anugrah, Chandra P., Pemanfaatan Teknologi Gadget Sebagai Media Pembelajaran. Universitas Muhammadiyah Palangkaraya. 2019.

Ginanjar, Gin, dkk., Penggunaan Gadget dalam Proses Pembelajaran Ilmu Pengetahuan Sosial Siswa Sekolah Dasar. 2. 2018.

Kurniawan, Dian. Pengaruh Pengguaan Gadget Terhadap Prestasi Siswa. Jurnal Ilmu Pendidikan. 2020.

Manab, A. Penelitian Pendidikan Pendekatan Kualitatif. Yogyakarta: Kalimedia. 2015.

Nuhman, Muhammad M., et al., Penggunaan Gadget Untuk Menciptakan Pembelajaran Yang Efektif. Jurnal Seminar Nasional Pendidikan. 2018.

Rimba, Agung K., et al., Kebijakan Sekolah Dalam Penggunaan Gadget di Sekolah Dasar. Jurnal Tunas Pendidikan. 2019.

Sa'adah. Dampak Penggunaan Gadget Terhadap Perilaku Sosial Siswa di MAN Cirebon 1 Kabupaten Cirebon. Skripsi (non publish). 2015.

Salim dan Syahrum. Metode Penelitian Kualitatif. Bandung:Ciptapustaka Media. 2012.

Sarif, Erni. Dampak Penggunaan Gadget dalam Lingkungan Sekolah. Kompasiana, (7 Oktober 2019). https://www.kompasiana.com/ ernisarif/5d9ac8c3b13fde56f248e293/dampak-penggunaan-gadget-dalamlingkungan-sekolah

Zulfa, Widya U., Kepribadian Ekstrovert dan Introvert pada Siswa Kelas VVI G SMP negeri 2 Ponorogo pada Proses Pembelajaran Dalam Prespektif Psikologi Sosial. Skripsi, Program Studi Ilmu Pengetahuan Sosial, Institut Agama Islam Negeri Ponorogo, 2020. 